\title{
First record of a bloom of the invasive species Ceratium furcoides (Levander) Langhans 1925 in Rio Grande do Sul state, Brazil
}

\author{
Cassol, APV.. ${ }^{a *}$, Pereira Filho, $W^{b}{ }^{b}$, Oliveira, $M A .^{a}$, Domingues, $A L .^{a}$, \\ Correa, FS. ${ }^{b}$ and Buriol, GA. ${ }^{a}$

\begin{abstract}
aPrograma de Pós-graduação em Agrobiologia, Universidade Federal de Santa Maria - UFSM, Av. Roraima, 1000, Cidade Universitária, Bairro Camobi, CEP 97105-900, Santa Maria, RS, Brazil

bPrograma de Pós-graduação em Geografia, Universidade Federal de Santa Maria - UFSM, Av. Roraima, 1000, Cidade Universitária, Bairro Camobi, CEP 97105-900, Santa Maria, RS, Brazil
\end{abstract} \\ *e-mail: anapvcassol@gmail.com
}

Received April 23, 2013 - Accepted April 29, 2013 - Distributed May 31, 2014 (With 3 figures)

Ceratium Schrank is dinoflagellate genus commonly found in marine environments, and considered invasive in continental waters (Silva et al., 2012). Species of this genus are able to develop blooms due to their mobility and resistance to sedimentation, to the occupation of the surface layer and optimised use of resources such as light and nutrients (Donagh et al., 2005). Even though its blooms are not toxic, they still bring harmful effects to aquatic communities as anoxic conditions causing the death of a local population of lobsters (Pitcher and Probyn, 2011).

In Brazil, the occurrence of a species of this genus has been recently registered in freshwater ecosystems. Santos-Wisniewski et al. (2007) recorded a bloom of C. furcoides in Furnas reservoir, Minas Gerais state, and Matsumura-Tundisi et al. (2010) in Billings reservoir, São Paulo state, both eutrophic enviroments. In the rivers semiarid region of Brazil the occurrences of $C$. furcoides and also of $C$. hirundinella were described by Oliveira et al. (2011). C. furcoides e C. hirundinella are ecologically and morphologically similar (Gil et al., 2012) differing only in the number of apical plates (Santos-Wisniewski et al., 2007).

Regarding Rio Grande do Sul state, the study by Cardoso et al. (2010) in four meso-eutrophic reservoirs identified eight species of Dinophyceae. Species of Ceratium, however, were not registered by these authors, so this genus had not, to date, been registered in freshwater reservoirs within the state. This note, thus, documents the first observation of a bloom of C. furcoides in Rio Grande do Sul state.

The upper Jacuí hydrographical basin located in Rio Grande do Sul, Brazil, has an area of 12.985,44 $\mathrm{km}^{2}$ and belongs to the Guaíba hydrographical region (Sema, 2009). The upper course of the Jacuí river is characterised by the presence hydroeletric power stations, where five water reservoirs were constructed forming a cascade system. Phytoplankton samples were collected in the water reservoir for the Itaúba Hydroeletrical power station. It is the fourth reservoir in the Jacuí cascading system. It has an area of $13.29 \mathrm{~km}^{2}$, a perimeter of $140.55 \mathrm{~km}$, and maximum depth of approximately $90 \mathrm{~m}$. Its main tributary is the river Ivaí (Sema, 2009).
On $31^{\text {th }}$ August 2012 four sampling stations (Figure 1) were visited and at each station samples were taken from three different depths (Figure 2). A five litre Van Dorn bottle was used to collect the water. The samples were concentrated in situ using a plankton net $(10 \mu \mathrm{m}$ pore size) and preserved with $1 \%$ Lugol solution. An analysis of the whole phytoplankton community was carried out and taxonomic identification to genus level followed Bicudo and Menezes (2006) and Santos-Wisniewski et al. (2007). Quantitative analyses followed Uthermöhl (1958) using an inverted microscope (Motic AE31).

Generally, the sampling stations at the Itaúba reservoir had an average depth of $45 \mathrm{~m}$. Water transparency varied between 0.50 and $1.65 \mathrm{~m}$ and the occurrence of $C$. furcoides (Figure 3) was registered at every sampling station in the reservoir.

In the phytoplankton community 36 species, belonging to eight classes were identified. Chlorophyceae and Bacillariophyceae were the classes with the highest species richness, but $C$. furcoides was the dominant species in all samples. In Figure 2 it is noticeable that the highest cell concentration was found at the sampling stations located close to the dam: Ss1 and Ss2. It is also clear that the concentration decreases with increasing distance to the barrage, shifting between $2036 \mathrm{cell} \cdot \mathrm{mL}^{-1}$ at Ss 1,1500 cell $\cdot \mathrm{mL}^{-1}$ at Ss 2 and 272 cell $\cdot \mathrm{mL}^{-1}$ at $\mathrm{Ss} 3$. Such densities may be considered high when compared to those found at Furnas reservoir: $285 \mathrm{cell} \cdot \mathrm{mL}^{-1}$ (Santos-Wisniewski et al., 2007) but relatively low when compared to the Billings reservoir: 21.000 cell $\cdot \mathrm{mL}^{-1}$ (Matsumura-Tundisi et al., 2010). Exceptionally at sampling station Ss4, where the lowest surface density $\left(74 \mathrm{cell} \cdot \mathrm{mL}^{-1}\right)$ was found, the lower limit of the euphotic zone was $4.95 \mathrm{~m}$. This lower density allowed light availability to a greater depth, where the vertical distribution of the species differed from the other sampling stations, with a higher density in the lower limit of the euphotic zone $\left(205 \mathrm{cell} \cdot \mathrm{ml}^{-1}\right)$.

Algal bloom events may cause harmful effects in aquatic communities, affecting the ecosystem balance, so constant monitoring is necessary. Furthermore, Itaúba reservoir is part of a cascading system, linked to a number of other reservoirs, where the occurrence of $C$. furcoides 


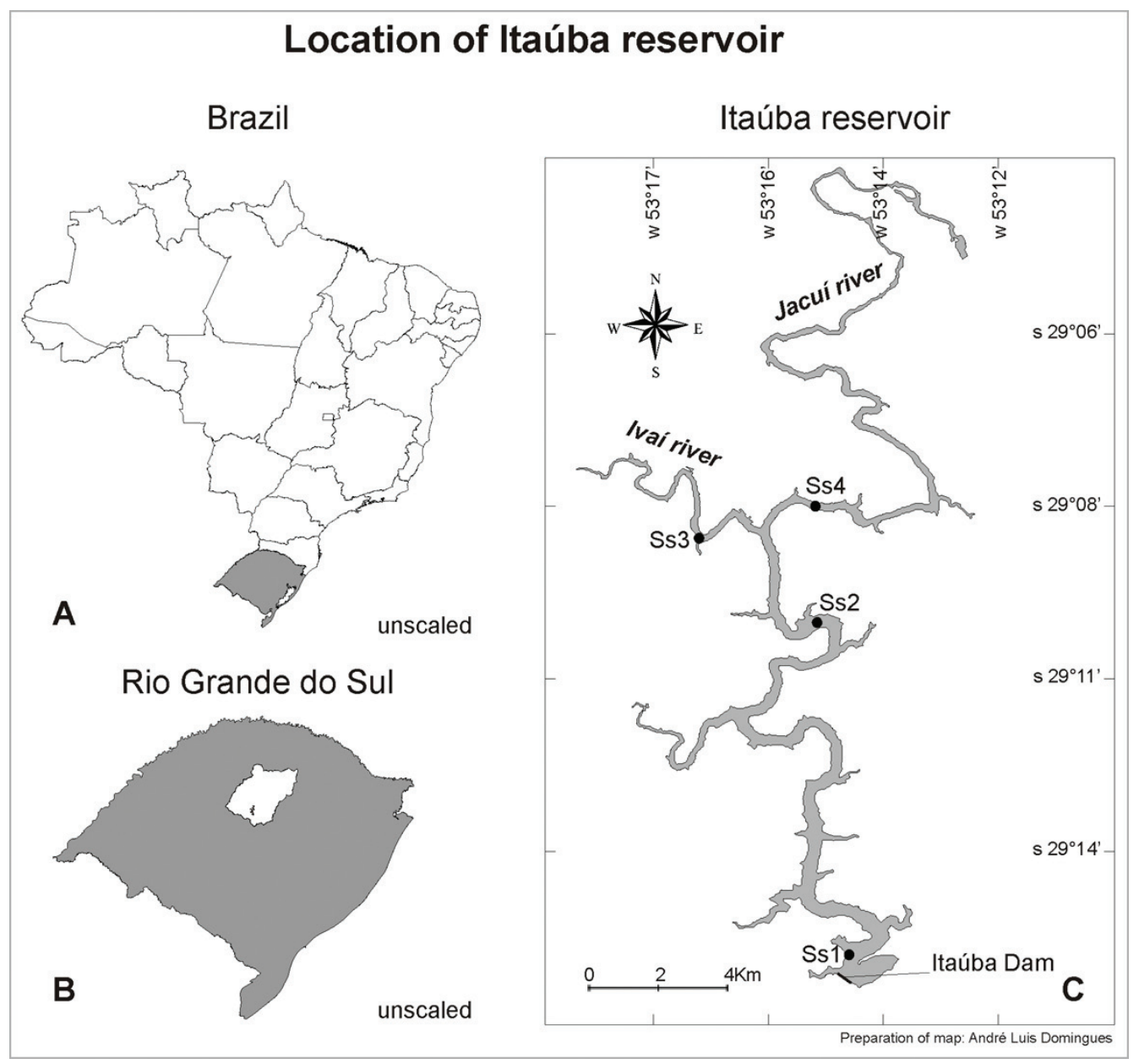

Figure 1. Location of Itaúba reservoir, (A) in grey Rio Grande do Sul state, southern Brazil; (B) in white the upper course of Jacuí hydrographical basin and the Itaúba reservoir; (C) Itaúba reservoir map with its main tributaries and the location of the four sampling stations (Ss).
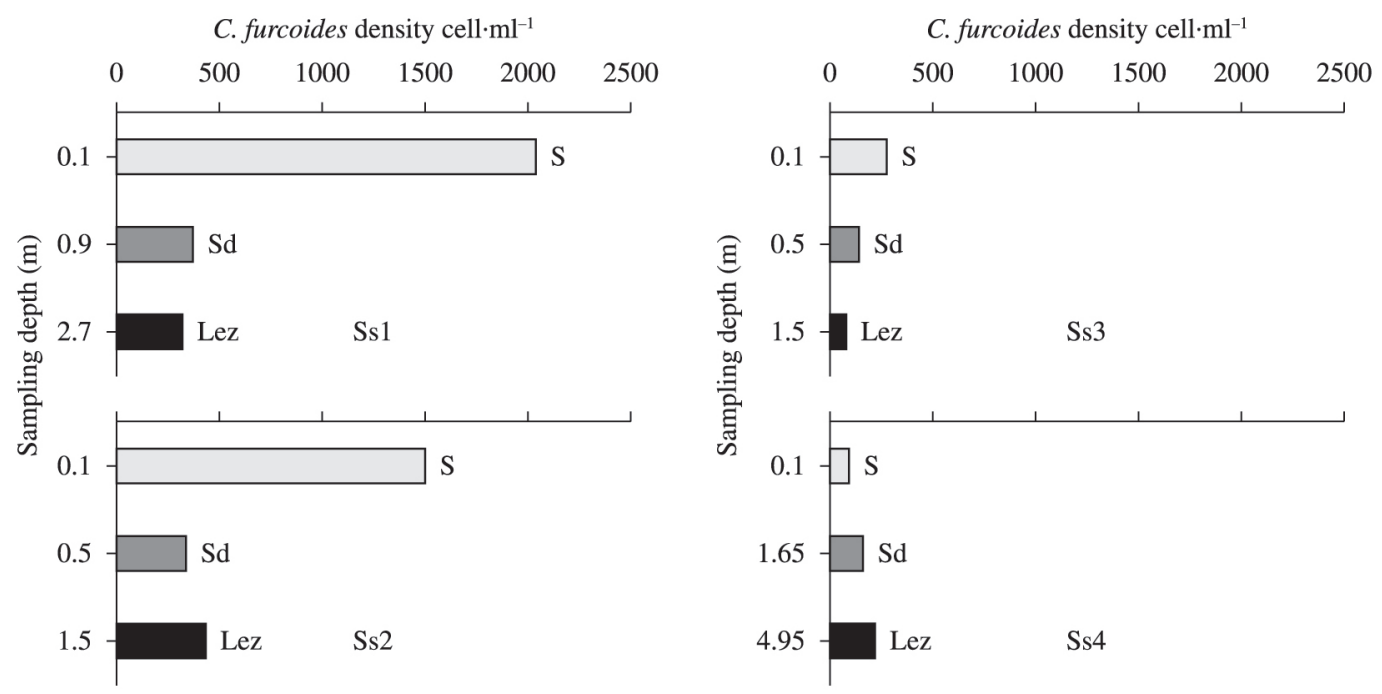

Figure 2. Cell density (cell $\cdot \mathrm{mL}^{-1}$ ) of Ceratium furcoides in four sampling stations (Ss) and three different depths in the Itaúba reservoir, August 2012. S: surface layer; ds: secchi disk depth; zf: lower limit of the photic zone. 


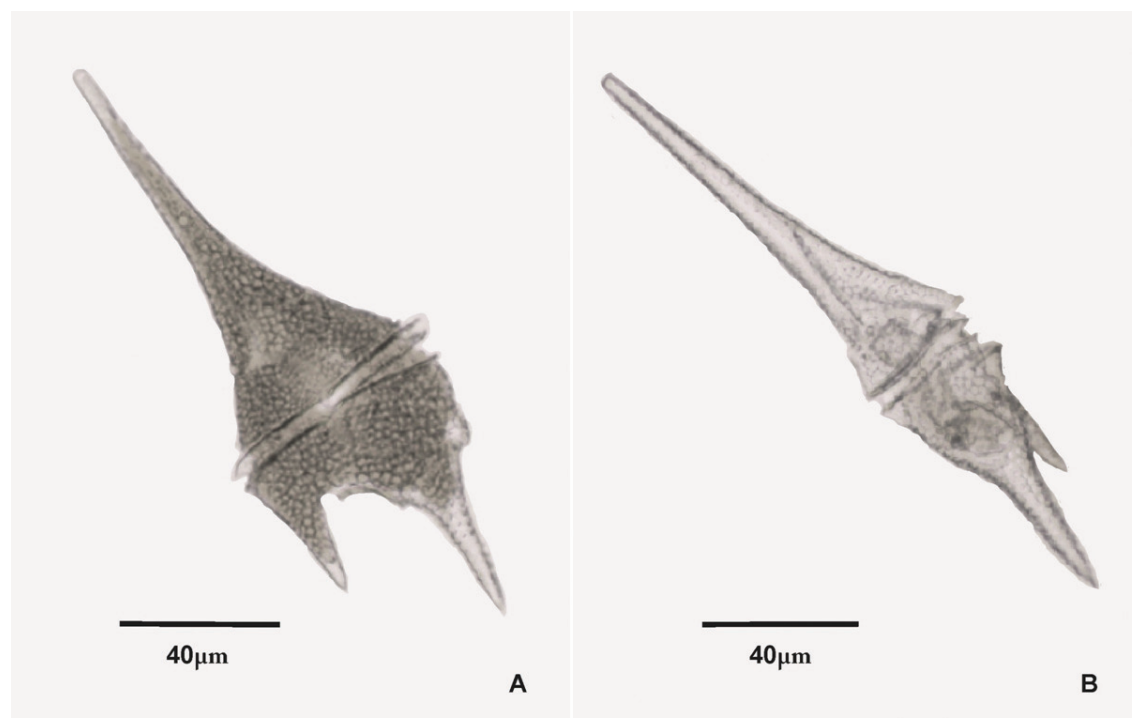

Figure 3. Ceratium furcoides (Levander) Langhans 1925. (A) dorsal view ; (B) lateral view. Length:173-150 $\mu \mathrm{m}(162 \mu \mathrm{m}$ average); width: 60-39 $\mu \mathrm{m}$ (45 $\mu \mathrm{m}$ average). (Photos: Domingues, A.L.).

is also under study, in order to describe the extent of the establishment of this invasive species in the hydrographical basin, its ability to form blooms and the interferences caused on the local communities.

Acknowledgements - The authors wish to thank CNPq for financial support (Research project 478961/2010-3) and to CAPES for MSc grants to Cassol, A.P.V. and Domingues, A.L.

\section{References}

BICUDO, CE.,M. and MENEZES, M., 2006. Gêneros de algas de águas continentais do Brasil: chave para identificação e descrições. 2. ed. São Paulo: Rima. 497 p.

CARDOSO, LS., FAGUNDES, PB. and BECKER, V., 2010. Spatial and temporal variations of Dinophyceae in subtropical reservoirs in southern Brazil. Hydrobiologia, vol. 654, no. 1, p. 205-214. http://dx.doi.org/10.1007/s10750-010-0382-9.

DONAGH, ME., CASCO, MA. and CLAPS, MC., 2005. Colonization of a Neotropical Reservoir (Córdoba, Argentina) by Ceratium hirundinella (O. F. Müller) Bergh. Annales de Limnologie - International. Journal of Limnology, vol. 41, no. 4, p. 291-299. http://dx.doi.org/10.1051/limn/2005020.

GIL, CB., RESTREPO, JJR., BOLTOVSKOY, A. and VALLEJO, A., 2012. Spatial and temporal change characterization of Ceratium furcoides (Dinophyta) in the equatorial reservoir Riogrande II, Colombia. Acta Limnologica Brasiliensia, vol. 24, no. 2, p. 207-219. http://dx.doi.org/10.1590/S2179-975X2012005000039.

MATSUMURA-TUNDISI, T., TUNDISI, JG., LUZIA, AP. and DEGANI, RM., 2010. Occurrence of Ceratium furcoides
(Levander) Langhans 1925 bloom at the Billings Reservoir, São Paulo State, Brazil. Brazilian Journal of Biology, vol. 70, no. 3, p. 825-829. PMid: 21085787. http://dx.doi.org/10.1590/S151969842010000400013.

OLIVEIRA, HSB., MOURA, AN. and CORDEIRO-ARAÚJO, MK., 2011. First record of Ceratium Schrank, 1973 (Dinophyceae: Ceratiaceae) in freshwater ecosystems in the semiarid region of Brazil. Check List, vol. 7, no. 5, p. 626-628.

PITCHER, GC. and PROBYN, TA., 2011. Anoxia in southern Benguela during the autumn of 2009 and its linkage to a bloom of the dinoflagellate Ceratium balechii. Harmful Algae, no. 11, p. 23-32.

SANTOS-WISNIEWSKI, MJA., SILVA, LC., LEONE, IC., LAUDARES-SILVA, RB. and ROCHA, O., 2007. First record of the occurrence of Ceratium furcoides (Levander) Langhans 1925 , an invasive species in the hydroelectricity power plant Furnas Reservoir, MG, Brazil. Brazilian Journal of Biology, vol. 67, no. 4, p. 791-793. PMid: 18278340. http://dx.doi.org/10.1590/ S1519-69842007000400033.

Secretaria Estadual do Meio Ambiente - SEMA,2009. Plano de gerenciamento da bacia hidrográfica do alto jacuí. Passo Fundo. 75 p. Relatório T2.

SILVA, LC., LEONE, CI., SANTOS-WISNIEWSKI, MJ., PERET, AC. and ROCHA, O., 2012. Invasion of the dinoflagellate Ceratium furcoides (Levander) Langhans 1925 at tropical reservoir and its relation to environmental variables. Biota Neotropica, vol. 12, no. 2, p. 93-100. http://dx.doi.org/10.1590/S1676-06032012000200010.

UTHERMÖHL, H., 1958. On the perfecting of quantitative phytoplankton method. International Association of Theoretical and Applied Limnology Commun, vol. 9, p. 1-38. 